\title{
Distribution and conservation status of Grifola frondosa (Polyporales, Basidiomycota) in Ukraine
}

\author{
Mariya V. SHEVCHENKO, Vasyl P. HELUTA, Vera P. HAYOVA \\ M.G. Kholodny Institute of Botany, National Academy of Sciences of Ukraine \\ 2 Tereschenkivska Str., Kyiv 01004, Ukraine \\ Shevchenko_Mariya@ex.ua
}

Shevchenko M.V., Heluta V.P., Hayova V.P. 2019. Distribution and conservation status of Grifola frondosa (Polyporales, Basidiomycota) in Ukraine. Ukrainian Botanical Journal, 76(2): 144-151.

Abstract. Grifola frondosa is a nationally red-listed species in Ukraine. In the third edition of the Red Data Book of Ukraine it is assigned to a category Vulnerable (VU). Previously, the fungus was known from 17 localities in nine regions of Ukraine: Cherkasy, Dnipropetrovsk, Donetsk, Kharkiv, Kherson, Kyiv, Sumy, Ternopil, Transcarpatian, and the Autonomous Republic of Crimea. Over the recent decade, G. frondosa has been also recorded in the following eight regions: Chernihiv, Chernivtsi, Ivano-Frankivsk, Khmelnytskyi, Lviv, Rivne, Volyn, Zhytomyr, and Kyiv city. Thus, a number of known up to now localities of $G$. frondosa increased from 17 to more than 40. However, the expanded number of records is due to additional data recently provided from field observations by amateur mycologists, rather than a result of the increasing population trend of the fungus. Based on the current distribution pattern of $G$. frondosa in Ukraine, its contemporary conservation status on the national level was evaluated using the IUCN categories and criteria. The species was assessed as Endangered, EN under criteria C2a(i). This is the higher threat category as compared to Vulnerable (VU) in the current edition of the Red Data Book of Ukraine. For conservation purposes, it is necessary to protect the already known sites, to search for new localities of the fungus, and to explore possibilities of its re-introduction into natural habitats. Global distribution and the Red List status of $G$. frondosa in Europe are briefly discussed. A list of currently known localities of the species in Ukraine and a distribution map of the reported sites are provided.

Keywords: assessment, fungal conservation, IUCN categories and criteria, Red Data Book of Ukraine

Шевченко М.В., Гелюта В.П., Гайова В.П. 2019. Поширення та природоохоронний статус Grifola frondosa (Polyporales, Basidiomycota) в Україні. Український ботанічний журнал, 76(2): 144-151.

Інститут ботаніки ім. М.Г. Холодного НАН України вул. Терещенківська 2, Київ 01004, Україна

Реферат. Grifola frondosa в Україні підлягає охороні на національному рівні. У третьому виданні "Червоної книги України" вид віднесений до категорії "уразливий" (VU). Раніше гриб був відомий з 17 локалітетів у дев'яти областях України - Дніпропетровській, Донецькій, Київській, Закарпатській, Сумській, Тернопільській, Харківській, Херсонській і Черкаській, а також в Автономній Республіці Крим. Упродовж останнього десятиліття G. frondosa була зареєстрована ще у восьми областях - Волинській, Житомирській, Івано-Франківській, Львівській, Рівненській, Чернівецькій, Чернігівській і Хмельницькій та в місті Києві. Таким чином, кількість відомих локалітетів виду зросла з 17 до понад 40. Однак це збільшення пов'язане насамперед з широким залученням до пошуків G. frondosa мікологіваматорів, а не є наслідком тенденції до збільшення чисельності гриба. На основі уточнених даних про поширення G. frondosa в Україні проведено оцінку природоохоронного статусу цього виду на національному рівні з використанням категорій і критеріїв МСОП. Вид оцінено як "зникаючий", EN за критеріями С2а(i). Ця категорія відповідає вищому ступеню загрози порівняно із категорією "уразливий" (VU) у третьому виданні "Червоної книги України". Надалі для збереження виду потрібно охороняти відомі його локалітети, проводити пошук нових місцезростань гриба та досліджувати можливість його реінтродукції до природних місць існування. У статті стисло обговорюються загальне поширення і природоохоронний статус $G$. frondosa в Європі. Наведено список відомих на сьогодні локалітетів та карта поширення цього виду в Україні.

Ключові слова: категорії та критерії МСОП, охорона грибів, оцінка виду, Червона книга України 


\section{Introduction}

Grifola frondosa (Dicks.) Gray (Polyporales, Basidiomycota) is a rarely recorded fungus in Ukraine and worldwide. It is a wood-inhabiting fungus forming its large annual fruit bodies on the ground near or at the base of old living or dead tree trunks or stumps. As a facultative parasitic or saprotrophic fungus, $G$. frondosa is capable of degrading lignin components of woody substrates, thus causing white rot or butt rot of tree stems or roots.

Most frequently $G$. frondosa is associated with old trees of Quercus spp. However, it may occur on other old-growth deciduous hardwoods, e.g. Acer L., Betula L., Carpinus L., Castanea Mill., Eucalyptus L'Hér., Fagus L., Juglans L., Populus L., and Ulmus L. (Ryvarden, Melo, 2014), with only a few known records on large conifers. Occurrence on conifers has been reported outside of Europe: on Pinus L., Pseudotsuga Carrière and Larix Mill. in North America (Gilbertson, Ryvarden, 1986), on Abies Mill. in China (https:// nt.ars-grin.gov/fungaldatabases/).

In Ukraine, the fungus has been so far recorded mostly on Quercus robur L., occasionally on Fagus sylvatica L. and, according to literature data (Gutsevich, 1940; Sarkina et al., 2003), once on Carpinus betulus L. In the current edition of the Red Data Book of Ukraine this species is listed as Vulnerable (Prydiuk, 2009). Prior to 2009, it was reported from 17 localities in nine regions of Ukraine: Cherkasy, Dnipropetrovsk, Donetsk, Kharkiv, Kherson, Kyiv, Sumy, Ternopil, Transcarpatian Regions, and the Autonomous Republic of Crimea. Recently, the fungus was found to occur in new localities in the western, central and northern parts of Ukraine.

This article presents an update on the current distribution of $G$. frondosa in Ukraine and results of the re-evaluation of its conservation status on the national level.

\section{Taxonomic notes}

Grifola frondosa (Dicks.) Gray, Nat. Arr. Brit. Pl. (London) 1: 643. 1821

The fungus was described as Boletus frondosus Dicks. in 1785 from Britain. In 1821, E. Fries changed the name to Polyporus frondosus (Dicks.) Fr. In the same year, S.F. Gray transferred the species to a new genus, Grifola Gray. Having made that combination, he established for this fungus its currently accepted name, Grifola frondosa. At present the species has over 20 homotypic and heterotypic synonyms. Although this fungus has a nearly worldwide distribution, molecular phylogenetic analysis revealed a strong support for species partition separating eastern North American and Asian isolates, as well as a distinct European lineage of $G$. frondosa (Shen et al., 2002). Thus, future taxonomic revision may split the species; in that case, the name $G$. frondosa is to be applied to the European lineage, with other two different names for the North American and Asian populations.

The genus Grifola is placed in the family Meripilaceae (Polyporales) (www.indexfungorum.org/), or in Fomitopsidaceae of the same order (www.mycobank. org/). Recently, based on molecular data (Justo et al., 2017), Grifolaceae Jülich, which appears as sister to Polyporaceae, was restored as an accepted family name to accommodate the genus Grifola.

\section{Global distribution and evaluation}

Grifola frondosa is traditionally regarded as a circumpolar species in the Northern Hemisphere where it has its major distribution. In this case, the fungus is considered as native to temperate hardwood regions of Europe, North America, and Asia (Bondartseva, 1998; Ryvarden, Melo, 2014). In North America it can be found in Eastern Canada, northeastern and mid-Atlantic states of the USA, and more rarely in northwestern or southeastern states (Chen et al., 2000). In Asia, it is known to occur in southwestern and northeastern China and northeastern Japan (Yamanaka, 1997; Chen et al., 2000). In the Southern Hemisphere, few records have been reported in Australasia (Australia, New Zealand) (Bondartseva, 1998). Although the fungus has a rather wide geographic distribution, it is a rarely occurring species throughout most of its range.

Since the eastern North American and Asian material may not be conspecific with the European records (see above), the recently proposed assessment of G. frondosa on the global level under the Global Fungal Red-List Initiative (http://iucn.ekoo.se/iucn/species_ view/362177) is based on the European populations.

\section{Red-list status in Europe}

In Europe, the reported conservation status of $G$. frondosa varies across the continent. In many countries the species is nationally red-listed under the threatened categories: Estonia - CR (Lõhmus et al., 2018), Bulgaria, Lithuania, North Macedonia EN (Gyosheva et al., 2006; Iršènaite et al., 2007; 


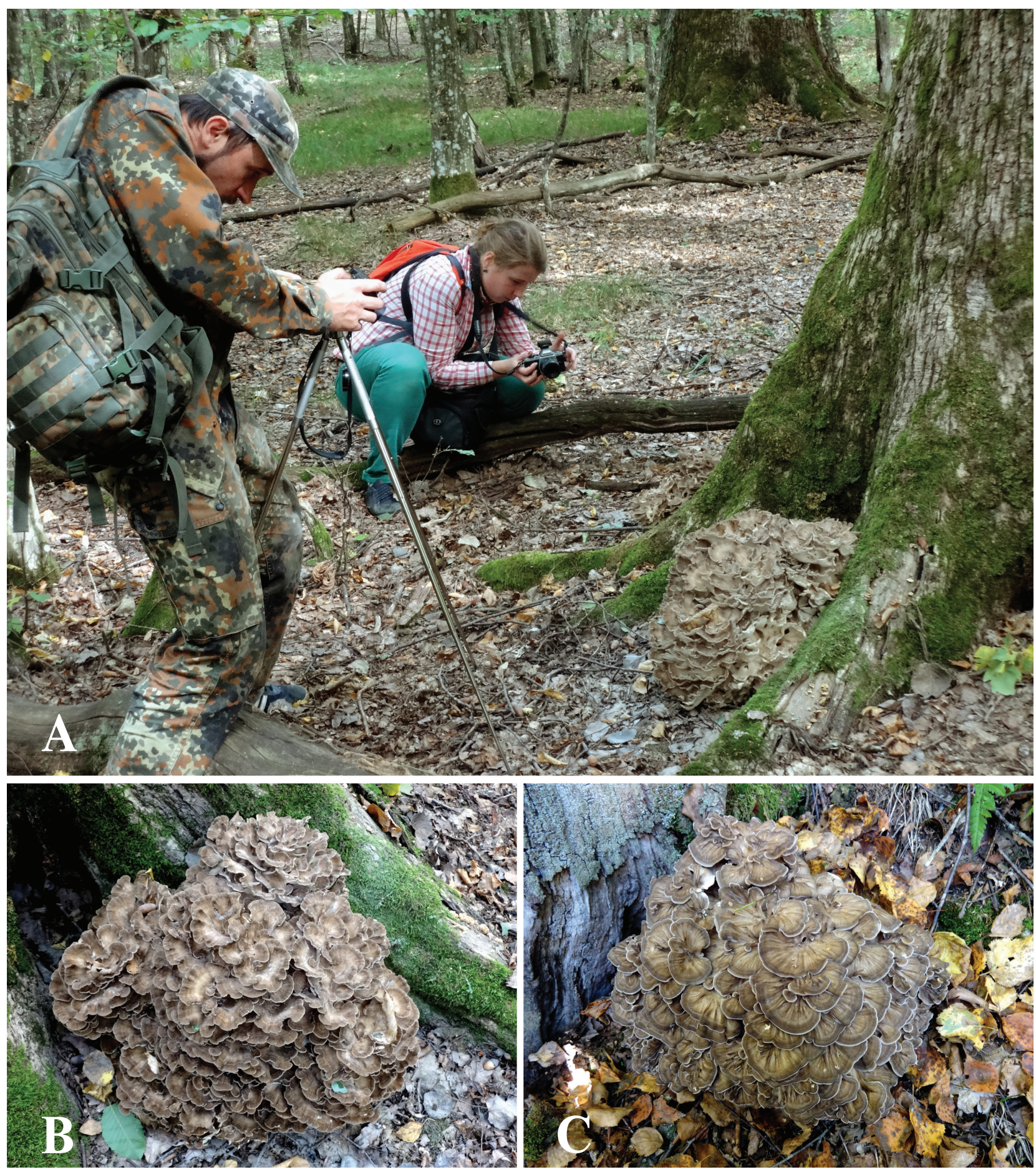

Fig. 1. Grifola frondosa. A: registration of parameters of two fruit bodies found at the base of an oak trunk; B, C: fruit bodies of the fungus 


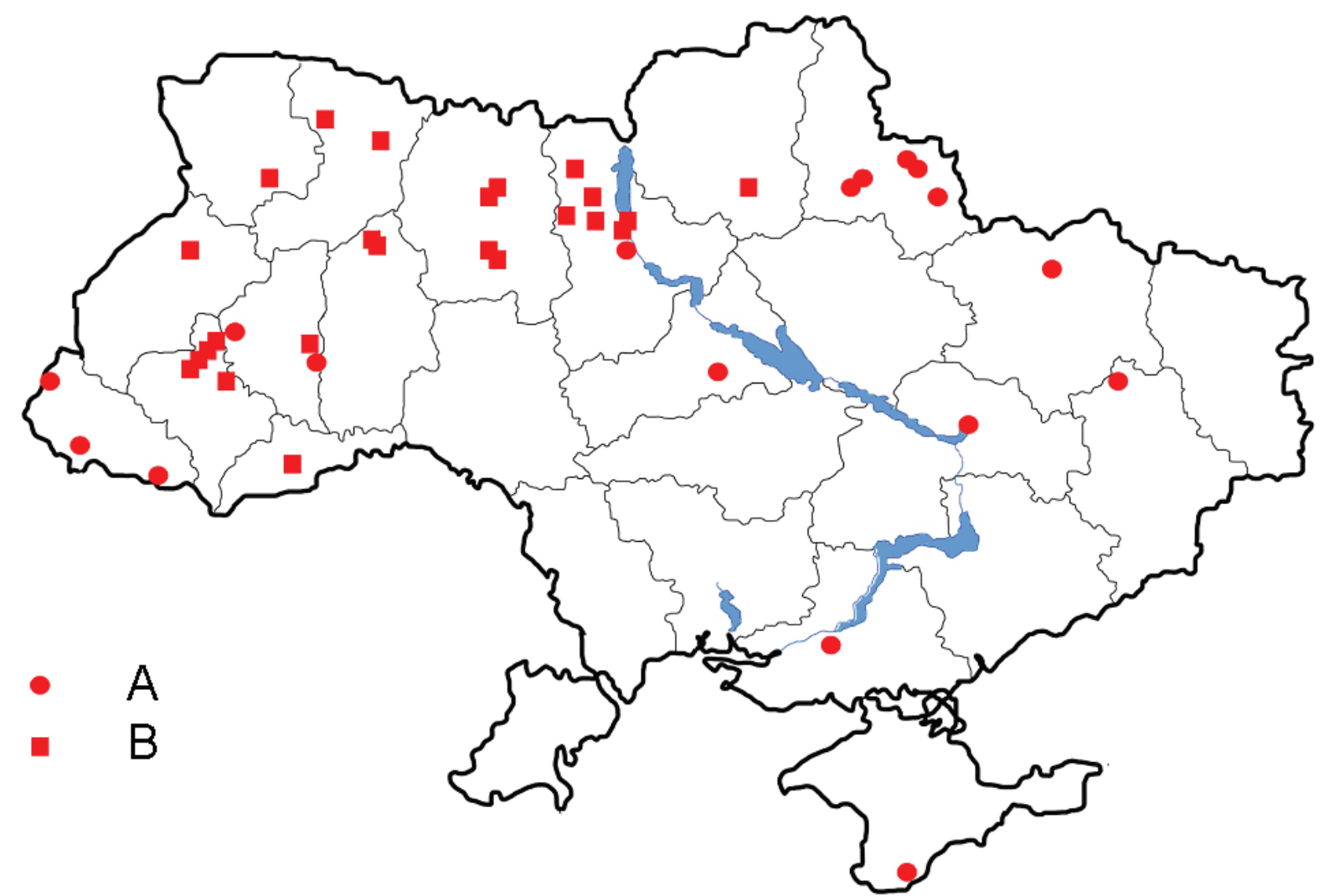

Fig. 2. Distribution of Grifola frondosa in Ukraine. A: as indicated in the Red Data Book of Ukraine (Prydiuk, 2009); B: recent data

Karadelev, Rusevska, 2013), Austria, Germany, Latvia, Norway, Poland, Ukraine - VU (Brandrud et al., 2006; Prydiuk, 2009; Matzke-Hajek et al., 2016; Dämon, Krisai-Greilhuber, 2017; http://www.eccf.eu/redlistsen.ehtml). In the Czech Republic, Romania and Sweden this species is listed as NT (Tănase, Adriana, 2005; Antonín et al., 2006; Westling, 2015); in Belarus and Russia it belongs to category 3 (Rare species) (Krasnaya..., 2005, 2008).

The major threat for $G$. frondosa is habitat destruction. Old-growth oak forests, particularly large size trees, are highly vulnerable. Many suitable habitats have been destroyed by deforestation, uncontrolled logging for timber in mature forests, replacement of slow-growing oak forests by plantations of fast-growing trees. In addition, in those areas where picking wild mushrooms is traditional, over-harvesting of large edible fruit bodies is also a threat.

\section{In vitro research in Ukraine and worldwide}

A large number of in vitro studies in Ukraine and other countries has demonstrated that $G$. frondosa is rich in a variety of polysaccharides which possess antitumor and immunostimulating activity as well as have antibiotic, antiviral and antioxidant properties (Kodama et al., 2002; Zhou, Wasser, 2004; Bartuv-Tal et al., 2009; Masuda et al., 2010; Linovytska et al., 2011; Bisko et al., 2018). Pharmacologically active substances derived from $G$. frondosa are widely used in pharmacognosy, in food production and as a source of biologically active compounds for dietary supplements. Apart from the advantages of nutritional value and medicinal effect, this fungus is famous for its delicious taste and appealing mushroom aroma. It is widely used in commercial growing and mushroom industry, particularly in Asia and North America. The world leader in production and consumption of $G$. frondosa is Japan where its 
annual production is estimated to be about 41,000 tonnes (Mayuzumi, Mizuno, 1997; Yamanaka, 2011).

In Ukraine, 29 strains of $G$. frondosa of different origin are currently maintained in the IBK mushroom culture collection of the M.G. Kholodny Institute of Botany, National Academy of Sciences of Ukraine, and one strain - in the FCKU culture collection of fungi of the Educational and Scientific Centre "Institute of Biology and Medicine", Taras Shevchenko National University of Kyiv (Bisko et al., 2016, 2018).

\section{Distribution in Ukraine}

Grifola frondosa forms large (up to $100 \mathrm{~cm}$ in diam.) multipileate grayish-brown basidiocarps (Fig. 1). They are easily recognizable and usually much looked after. Apart from literature data, herbarium materials, and our personal field observation results (Fig. 1, A), we have also analysed reports published by amateur mycologists in two social network groups (https://www.facebook. com/groups/Hryby.Ukrayiny/?ref=bookmarks,https:// www.facebook.com/groups/119266158163241/), if and when these newly reported records were confirmed by photographs. Altogether, a number of known up to now localities $G$. frondosa was expanded from 17 indicated in the current edition of the Red Data Book of Ukraine to over 40. For the first time, the fungus was reported in the following eight regions: Chernivtsi, Chernihiv, IvanoFrankivsk, Lviv, Khmelnytsky, Rivne, Volyn, Zhytomyr, and Kyiv city. However, the expanded number of the recently reported records is due to additional field observations in appropriate habitats undertaken by amateur mycologists, rather than a result of increasing population trend of the fungus.

Below we provide a list of all currently known localities of $G$. frondosa in Ukraine. Since the species is nationally red-listed, according to the Ukrainian legislation on the Red Data Book of Ukraine (Zakon..., 2017), its published distribution data do not include information on the exact localities. All reported sites are shown on the map (Fig. 2).

Autonomous Republic of Crimea: near Alushta, Crimean Nature Reserve, autumn 1936, S.A. Gutsevich (Gutsevich, 1940; Sarkina et al., 2003).

Cherkasy Region: Smila District, near Smila (Bondartsev, 1953).

Chernihiv Region: Ichnya District, Ichnyanskyi National Nature Park, 16.10.2016 (Shevchenko, 2018).

Chernivtsi Region: Hlyboka District, 27.09.2007, M.D. Nykyrsa (Volutsa, 2014).
Dnipropetrovsk Region: Novomoskovsk District (Taran et al., 1989).

Donetsk Region: Slovyansk District, October 2003 (Triskiba et al., 2005; Leshan, Pakhomov, 2009).

Ivano-Frankivsk Region: Galych District, Galytskyi National Nature Park (Malanyuk, 2012); Burshtyn, 27.09.2018, I. Zubrytsky; Kalush District, 03.10.2018, V. Petriv; Tismenytsia District, 31.08.2016, 21.09.2016, 29.09.2018, S. Labuz'ko.

Kharkiv Region: Kharkiv District, near Kharkiv (Bondartsev, 1953).

Kherson Region: Oleshky District (Prydiuk, 2009).

Khmelnytsky Region: Izyaslav District, Male Polissya National Nature Park, 09.10.2017, N. Kratasyuk; ibid., 17.09.2018, O. Mnyukh et al.; Slavuta District, Male Polissya National Nature Park, 09.16.2018, V.P. Heluta, M.P. Prydiuk, V.P. Hayova.

Kyiv city, Holosiiv National Nature Park, 13.10.2009, M. Shevchenko; October 2009 (Ivanenko, 2014); Feofaniya park, September 2012-2013 (Ivanenko, 2014); 15.09.2018, A. Cherenkova.

Kyiv Region: Borodyanka District, 08.09.2018, A. Cherednichenko; Ivankiv District, 24.09.2017, K. Oleynik; Kyiv-Svyatoshinsky District, 20.09.1985, T.L. Horova (KW-M 2716); Makariv District, 23.10.2017, V. Hnatenko; Obukhiv District, 23.09.2018, L. Prokopova, Ye. Rudenko; 30.09.2018, V. Mykolaenko. Lviv Region: Zhovkva District, 27.09.2018, O. Stadnyk.

Rivne Region: Volodymyrets District, 23.09.2017, O. Shatkovs'ka; Sarny District, 30.09.2018, M. Mel'nyk.

Sumy Region: Krasnopillya District, 13.10.2002 (Karpenko, 2004); Nedrigailiv District, 12.10.2002 (Karpenko, 2004); Romny District (Chala, Karpenko, 2012); Sumy District, 20.10.2000 (Karpenko, 2004); Trostyanets District, 06.10.1996 (Karpenko, 2004).

Ternopil Region: Berezhany District (Namysłowski, 1914); Husyatyn District, Medobory Nature Reserve, 17.07.2008, M.P. Pridyuk (Dzhagan et al., 2010); Chortkiv District, August 1935 (Pilát, 1940).

Transcarpathian Region: Perechyn District, 13.08.1982, N.Yu. Mytropolska (KW-M 19583); Rakhiv District, August 1934 (Pilát, 1940; Bondartsev, 1953); Carpathian Biosphere Reserve (Lovas, Küffer, 2006).

Volyn Region: Lutsk District, 14.07.2017, V.V. Revnyuk.

Zhytomyr Region: Zhytomyr District, 08.09.2018, V. Yakymchuk; 28.10.2018, O. Volynchuk; Malyn District, 29.09.2018, S. Stepanyuk; Khoroshiv District, 23.09.2017, Z. Kosyns'ka. 


\section{Assessment and conservation status in Ukraine}

After having updated its current distribution in Ukraine, we evaluated $G$. frondosa on the national level using the IUCN Red List Categories and Criteria (IUCN Red List Categories and Criteria, 2012).

The species is assessed under criterion C (Small population size and decline) based on the number of mature individuals. The calculation was made according to the concept of functional individual (Dahlberg, Mueller, 2011), now generally accepted in fungal redlisting. Thus, the currently known number of localities of the fungus is about 40. Since $G$. frondosa is associated exclusively with old-growth oak trees (or rarely beech trees), maximum actual number of the localities can be increased tenfold, apparently not exceeding 400 . For $G$. frondosa as a lignicolous fungus, sporocarps inhabiting individual tree may represent one functional individual. Since each functional individual should be counted at minimum as two mature individuals, in our case total number of mature individuals is equal to 800 . As $G$. frondosa may not fruit every year under the same tree, if to suggest that one or two fruit bodies under individual tree correspond to four mycelia, the total number of mature individuals would not exceed 1600. In addition, large old-growth oak and beech trees are under long-term ongoing decline. Hence, number of mature individuals is $<2.500$; there is an observed, estimated, projected or inferred continuing decline $(\mathrm{C} 2)$; number of mature individuals in each subpopulation is $<250$. Therefore, the species is assessed as Endangered (EN) under criteria $\mathrm{C} 2 \mathrm{a}(\mathrm{i})$.

\section{Conclusion}

Based on our update on distribution of $G$. frondosa in the country, the species was assessed nationally as Endangered (EN) which is the higher threat category as compared to Vulnerable (VU) in the current edition of the Red Data Book of Ukraine. It is therefore necessary for conservation purposes to protect the already known sites, to search for new localities of the fungus in appropriate habitats, and to explore potential reintroduction of the strains of local origin into natural habitats. Thus, in the next edition of the Red Data Book of Ukraine, the conservation status of $G$. frondosa should be indicated as EN C2a(i).

\section{Acknowledgements}

The authors are grateful to all amateur mycologists from various regions of the country who provided additional data on distribution of $G$. frondosa.

Our research was supported by the program "Support for development of priority areas of scientific research" (CPCEL 6541230).

\section{REFERENCES}

Antonín V., Beran M., Bieberová Z., Borovička J., Burel J., Č́žek K., Deckerová H., Dvořák D., Edrová L., Graca M., Holec J., Hrouda P., Janda V., Jindřich O., Kotlaba F., Pouzar Z., Svrček M., Šutara J., Vampola P., Vašutová M., Vágner A., Zelený L., Zíta V. 2006. Červený seznam hub (makromycetů) České republiky. Praha: Př́roda, 282 pp.

Bartuv-Tal J., Mahajna J.A., Wasser S.P., Nevo E. 2009. Secondary metabolites from edible and medicinal mushrooms as potential therapeutics for colon cancer. In: Book of abstracts International Medicinal Mushroom Conference (Nantong, 5-8 September 2009). Nantong, China, pp. 194-195.

Bisko N.A., Linovytska V.M., Polozyuk Yu.V. 2018. In: The Plant Kingdom in the Red Data Book of Ukraine. Implementing the Global Strategy for Plant Conservation. Proceedings of the $5^{\text {th }}$ International Conference. Kherson: FOP Vyshemyrskyi, pp. 146-148. [Бісько Н.А., Ліновицька В.М., Полозюк Ю.В. 2018. Біологічні особливості рідкісного лікарського гриба Grifola frondosa (Meripilaceae, Polyporales) у культурі за різних температур. У зб.: Рослинний світ у Червоній книзі Украӥни: впровадження Глобальної стратегї̈ збереження рослин: матеріали V Міжнародної конференції (25-28 червня 2018 р., м. Херсон). Херсон: ФОП Вишемирський, с. 146-148].

Bisko N.A., Lomberh M.L., Mytropolska N.Yu., Mykchaylova O.B. 2016. Kolektsiya kultur shapynkovykh hrybiv $(I B K)$. Kyiv: Alterpress, 120 pp. [Бісько H.A., Ломберг М.Л., Митропольська Н.Ю., Михайлова О.Б. 2016. Колекція культур шапинкових грибів $(I B K)$. Київ: Альтерпрес, 120 с.].

Bisko N.A., Sukhomlyn M.M., Mykchaylova O.B., Lomberg M.L., Tsvyd N.V., Petrichuk Yu.V., Al-Maali G.A., Mytropolska N.Yu. 2018. Ex situ conservation of rare and endangered species in mushroom culture collections of Ukraine. Ukrainian Botanical Journal, 75(4): 338-347.

Bondartsev A.S. 1953. Trutovye griby evropeyskoy chasti SSSR i Kavkaza. Moscow; Leningrad: Izd-vo AN SSSR, 1106 pp. [Бондарцев А.С. 1953. Трутовые грибы европейской части СССР и Кавказа. Москва; Ленинград: Изд-во АН СССР, 1106 с.

Bondartseva M.A. 1998. Opredelitel gribov Rossii, vyp. 2. St. Petersburg: Nauka, 391 pр. [Бондарцева M.A. 1998. Определитель грибов России, вып. 2. СПб.: Наука, 391 c.].

Brandrud T.E., Bendiksen E., Hofton T.H., Høiland K., Jordal J.B. 2006. Fungi. In: Norsk Rødliste 2006-2006 Norwegian Red List. Eds J.A. Kålås, Å. Viken, T. Bakken. Norway: Artsdatabanken, pp. 103-128. 
Chala T.M., Karpenko K.K. 2012. Makromitsety Pustoviytivskoho hidrolohichnoho zakaznyka Romenskoho rayonu Sumskoi oblasti. Pryrodnychi nauky: zbirnyk naukovykh prats, SumDPU, 9: 33-36. [Чала T.M., Карпенко Е.К. 2012. Макроміцети Пустовійтівського гідрологічного заказника Роменського району Сумської області. Природничі науки: збірник наукових праць, СумДПУ, 9: 33-36].

Chen A.W., Stamets P.E., Cooper R.B., Huang N.L., Han S.-H. 2000. Ecology, morphology, and morphogenesis in nature of edible and medicinal mushroom Grifola frondosa (Dicks.: Fr.) S.F.Gray - Maitake (Aphyllophoromycetideae). International Journal of Medicinal Mushrooms, 2(3): 221-228. https://doi. org/10.1016/j.funeco.2010.11.001

Dahlberg A., Mueller G.M. 2011. Applying IUCN Red Listing Criteria for assessing and reporting on the conservation status of fungal species. Fungal Ecology, 4: 147-162.

Dämon W., Krisai-Greilhuber I. 2017. Die Pilze Österreichs. Verzeichnis und Rote Liste 2016. Teil: Makromyzeten. Österreichische Mykologische Gesellschaft, 608 S.

Dzhagan V.V., Prydiuk M.P., Senchylo O.O. 2010. New records of macromycetes listed in the Red Data Book of Ukraine. Ukrainian Botanical Journal, 67(4): 587-595. [Джаган В.В., Придюк М.П., Сенчило О.О. 2010. Нові знахідки макроміцетів, занесених до "Червоної книги України". Український ботанічний журнал, 67(4): 587-595].

Gilbertson R.L., Ryvarden L. 1986. North American Polypores, vol. 1. Oslo: Fungiflora, 443 pp.

Gutsevich S.A. 1940. Gimenomitsety osnovnikh drevesnykh porod Krymskogo zapovednika. Trudy Krymskogo gosudarstvennogo zapovednika, 2: 3-37. [Гуцевич С.А. 1940. Гименомицеты основних древесных пород Крымского заповедника. Труды Крымского государственного заповедника, 2: 3-37].

Gyosheva M.M., Denchev C.M., Dimitrova E.G., Assyov B., Petrova R.D., Stoichev G.T. 2006. Red List of fungi in Bulgaria. Mycologia Balcanica, 3: 81-87.

Iršènaitè R., Kutorga E., Kasparavičius J., Motiejūnaitė J. 2007. Karalystė Grybai (Fungi) [Kingdom Fungi (Fungi)]. In: Lietuvos Raudonoji knyga [Red Data Book of Lithuania]. Ed. V. Rašomavičius. Kaunas: Lututè, pp. 617-789.

IUCN Red List Categories and Criteria. 2012. Version 3.1, Second edition. Available at: https://www.iucnredlist. org/resources/categories-and-criteria (accessed 20 February 2019).

Ivanenko O.M. 2014. In: The Plant Kingdom in the Red Data Book of Ukraine. Implementing the Global Strategy for Plant Conservation. Proceedings of the $3^{\text {rd }}$ International Conference. Lviv: Prostir-M, pp. 182-183. [Іваненко О.М. 2014. Нові місцезнаходження видів афілофороїдних грибів, занесених до Червоної книги. В зб.: Рослинний світ у Червоній книзі України: впровадження Глобальної стратегії збереження рослин: матеріали III Міжнародної конференції (4-7 червня 2014 р., м. Львів). Львів: Простір-М, с. 182-183].
Justo A., Miettinen O., Floudas D., Ortiz-Santana B., Sjökvist E., Lindner D., Nakasone K., Niemelä T., Larsson K.H., Ryvarden L., Hibbett D.S. 2017. A revised family-level classification of the Polyporales (Basidiomycota). Fungal Biology, 121(9): 798-824. https://doi.org/10.1016/j.funbio.2017.05.010

Karadelev M., Rusevska K. 2013. Contribution to Macedonian Red List of fungi. In: Proceedings of the $4^{\text {th }}$ Congress of Ecologists of Macedonia with International Participation (Ohrid, 12-15 October 2012). Macedonian Ecological Society, Special issue 28, pp. 68-73.

Karpenko K.K. 2004. New and rare for Ukraine species of macromycetes from the north-east part of the Left-Bank Forest-Steppe. Ukrainian Botanical Journal, 61(2): 3435. [Карпенко К.К. 2004. Нові та рідкісні для України види макроміцетів із північно-східної частини Лівобережного Лісостепу. Український ботанічний журнал, 61(2): 34-35].

Kodama N., Komuta K., Sakai N., Nanba H. 2002. Effects of D-Fraction, a polysaccharide from Grifola frondosa on tumor growth involve activation of NK cells. Biological and Pharmaceutical Bulletin, 25(12): 1647-1650.

Krasnaya kniga Respubliki Belarus: Redkie i nakhodyashchiesya pod ugrozoy ischeznoveniya vidy dikorastushchikh rasteniy. 2005. Eds L.I. Khoruzhik, L.M. Sushchenya, V.I. Parfenov. Minsk: BelEn, 456 pp. [Красная книга Республики Беларусь: Редкие и находящиеся под угрозой исчезновения виды дикорастущих растений. 2005. Ред. Л.И. Хоружик, Л.М. Сущеня, В.И. Парфенов. Минск: БелЭн, 456 с.].

Krasnaya kniga Rossiyskoy Federatsii (rasteniya $i$ griby). 2008. Eds L.V. Bardunov, V.S. Novikov. Moscow: Tov-vo nauchnykh izdaniy KMK, 856 pp. [Красная книга Российской Федерации (растения и грибы). 2008. Отв. ред. Л.В. Бардунов, В.С. Новиков. Москва: Тов-во научных изданий КМК, 856 с.].

Leshan T.A., Pakhomov O.Ye. 2009. Rarytetnyi fond bazydiomitsetiv Skhodu Ukrainy. Visnyk Dnipropetrovskoho universytetu. Biolohiya. Ekolohiya, 17(1): 115-120. [Лешан T.A., Пахомов О.Е. 2009. Раритетний фонд базидіоміцетів Сходу України. Вісник Дніпропетровського університету. Біологія. Екологія, 17(1): 115-120].

Linovytska V.M., Bukhalo A.S., Duhan O.M. 2011. Pidbir umov hlybynnoho kultyvuvannya Grifola frondosa yak osnovy dlya stvorennya biotekhnolohiy otrymannya likuvalno-profilaktychnykh preparativ. Naukovi visti NTUU KPI, 3: 56-60. [Ліновицька В.М., Бухало А.С., Дуган О.М. 2011. Підбір умов глибинного культивування Grifola frondosa як основи для створення біотехнологій отримання лікувально-профілактичних препаратів. Наукові вісті Національного технічного університету України "КПГ", 3: 56-60].

Lõhmus A., Vunk E., Runnel K. 2018. Conservation management for forest fungi in Estonia: the case of polypores. Folia Cryptogamica Estonica, 55: 79-89. https://doi. org/10.12697/fce.2018.55.08

Lovas P., Küffer N. 2006. Aphyllophorales fungi of natural beech forests of Carpathian Biosphere reserve and managed beech forests of Switzerland Alps. Naukovyi 
visnyk Uzhhorodskoho universytetu. Seriya Biolohiya, 60: 60-65. [Ловас П.С., Куффер Н. 2006. Афілофоральні гриби букових пралісів Карпатського біосферного заповідника та господарських бучин Швейцарських Альп. Науковий вісник Ужггородського університету. Серія Біологія, 60: 60-65].

Malanyuk V.B. 2012. Hryby Chervonoi knyhy Ukrainy v obyektakh pryrodno-zapovidnoho fondu Karpatskoho rehionu. Naukovyi visnyk Natsionalnoho universytetu bioresursiv $i$ pryrodokorystuvannya Ukrainy. Seriya Lisivnytstvo ta dekoratyvne sadivnytstvo, 171(1): 124-127. [Маланюк В.Б. 2012. Гриби Червоної книги України в об'єктах природно-заповідного фонду Карпатського регіону. Науковий вісник Національного університету біоресурсів $і$ природокористування України. Серія Лісівництво та декоративне садівництво, 171(1): 124-127].

Masuda Y., Ito K., Konishi M., Nanba H. 2010. A polysaccharide extracted from Grifola frondosa enhances the anti-tumor activity of bone marrow-derived dendritic cell-based immunotherapy against murine colon cancer. Cancer Immunology, Immunotherapy, 59(10): 1531-1541.

Matzke-Hajek G., Hofbauer N., Ludwig G. (Eds). 2016. Rote Liste gefaehrdeter Tiere, Pflanzen und Pilze Deutschlands, Pilze. Teil 1: Grosspilze. Naturschutz und Biologische Vielfalt, 70(8): 1-444.

Mayuzumi Y., Mizuno T. 1997. Cultivation methods of maitake (Grifola frondosa). Food Reviews International, 13: $357-364$.

Namysłowski B. 1914. Śluzowce i grzyby Galicyi i Bukowiny. Pamętnik Fizyograficzny, 22(4): 1-151.

Pilát A. 1940. Hymenomycetes Carpatorum orientalium. Acta Musei Nationalis Pragae, 2(3): 37-80.

Prydiuk M.P. 2009. Grifola frondosa. In: Chervona knyha Ukrainy. Roslynnyi svit (Red Data Book of Ukraine. Plant Kingdom). Ed. Ya.P. Didukh. Kyiv: Globalconsulting, p. 817. [Придюк М.П. 2009. Grifola frondosa (Dicks.: Fr.) Gray. У кн.: Червона книга Украӥни. Рослинний світ. Ред. Я.П. Дідух. Київ: Глобалконсалтинг, 817 с.].

Ryvarden L., Melo I. 2014. Poroid fungi of Europe. Synopsis Fungorum, 31: 1-456.

Sarkina I.S., Prydiuk M.P., Heluta V.P. 2003. Macromycetes of Crimea listed in the Red Data Book of Ukraine. Ukrainian Botanical Journal, 60(4): 438-446. [Саркіна I.C., Придюк М.П., Гелюта В.П. 2003. Макроміцети Криму, занесені до Червоної книги України. Український ботанічний журнал, 60(4): 438-446].

Shen Q., Geiser D., Royse D. 2002. Molecular phylogenetic analysis of Grifola frondosa (maitake) reveals a species partition separating eastern North American and Asian isolates. Mycologia, 94(3): 472-482. http://dx.doi. org/10.2307/3761781

Shevchenko M.V. 2018. In: The Plant Kingdom in the Red Data Book of Ukraine. Implementing the Global Strategy for Plant Conservation. Proceedings of the $5^{\text {th }}$ International
Conference. Kherson: FOP Vyshemyrskyi, pp. 136137. [Шевченко М.В. 2018. Рідкісні види афілофороїдних грибів в Ічнянському національному природному парку (Чернігівська обл.). У зб.: Рослинний світ у Червоній книзі України: впровадження Глобальної стратегії збереження рослин: матеріали V Міжнародної конференції (25-28 червня 2018 р., м. Херсон). Херсон: ФОП Вишемирський, с. 136-137].

Tănase C., Adriana P. 2005. Red List of Romanian Macrofungi Species. In: Bioplatform-Romanian National Platform for Biodiversity. Bucureşti: Academiei Române, pp. 101-107.

Taran N.A., Soldatova I.M., Wasser S.P. 1989. Markomitsety Prisamarskogo lesa. In: Biogeotsenologicheskie issledovaniya lesov tekhnogennykh landshaftov stepnoy Ukrainy. Dnepropetrovsk: DGU, pp. 58-73. [Таран Н.A., Солдатова И.М., Вассер С.П. 1989. Маркомицеты Присамарского леса. В кн.: Биогеоценологические исследования лесов техногенных ландшафтов степной Украины. Днепропетровск: ДГУ, с. 58-73].

Triskiba S.D., Polokhina I.I., Sukhomlyn M.M. 2005. About presence Grifola frondosa (Fr.) S. Gray in the north of Donetsk ares. Ukrainian Botanical Journal, 62(1): 8790. [Трискиба С.Д., Полохіна I.I., Сухомлин М.М. 2005. Знахідка Grifola frondosa (Fr.) S.Gray на півночі Донецької області. Український ботанічний журнал, 62(1): 87-90].

Volutsa O.D. 2014. In: The Plant Kingdom in the Red Data Book of Ukraine. Implementing the Global Strategy for Plant Conservation. Proceedings of the $3^{\text {th }}$ International Conference. Lviv: Prostir-M, pp. 176-181. [Волуца О.Д. 2014. Нові відомості щодо поширення раритетних видів макроміцетів у Чернівецькій області. В зб.: Рослинний світ у Червоній книзі України: впровадження Глобальної стратегії збереження рослин: матеріали III Міжнародної конференції (4-7 червня 2014 р., м. Львів). Львів: Простір-М, с. 176-181].

Westling A. (Ed.) 2015. Rödlistade arter $i$ Sverige 2015. Uppsala: ArtDatabanken, 209 pp.

Yamanaka, K. 1997. I. Production of cultivated edible mushrooms. Food Reviews International, 13(3): 327-333. http://dx.doi.org/10.1080/87559129709541113

Yamanaka K. 2011. Mushroom cultivation in Japan. Bulletin of World Society for Mushroom Biology and Mushroom Products, 4: 1-10.

Zakon Ukrainy pro Chervonu knyhu Ukrainy [Закон України про Червону книгу України (Редакція від 05.03.2017)]. Available at: http://zakon5.rada.gov.ua/laws/show/3055-14

Zhou C., Wasser S.P. 2004. Medicinal value of culinarymedicinal maitake mushroom Grifola frondosa (Dicks.: Fr.) S.F.Gray (Aphyllophoromycetideae). Rewiew. International Journal of Medicinal Mushrooms, 6(4): 287-313.

Recommended for publication by

Submitted 25.02.2019

M.M. Sukhomlyn 